\title{
Menuju Pemulihan Kepemimpinan Gereja Berdasarkan Eksposisi Yesaya 42:1-9
}

\section{Daniel Ronda}

\section{Pendahuluan}

Sebagai organisasi, gereja dalam sejarahnya juga mengalami pasang surut. Jika berbicara organisasi maka gereja seringkali mengalami perkembangan dan penurunan dari segi manajemen, di mana kepemim-pinan ditengarai menjadi penyebab utamanya. Ciri-ciri gereja mengalami masa-masa surut dapat terlihat dari adanya konflik, kelesuan rohani, rutinitas, stagnansi penurunan jumlah keanggotaan, penurunan keuangan, serta tantangan eksternal lainnya berupa penganiyaan dan kondisi masyarakat yang tertutup dan resisten terhadap Injil. Ini menjadi suatu siklus yang secara alamiah dialami gereja. Agung Gunawan juga menambahkan bahwa konflik yang ada dalam gereja dapat dilihat dari penurunan partisipasi jemaat, banyaknya keluhan dan adanya perubahan perilaku hamba Tuhan yang menjadi pasif dan mulai defensif. ${ }^{1}$

Tulisan ini ingin memberikan pemahaman kepada pemimpin tentang siklus yang pasti akan dialami gereja dan bagaimana melihat tanda-tanda gereja yang mulai mengalami penurunan dan bagaimana pemimpin gereja dapat terlibat dalam memulihkannya. Kata kuncinya ada pada pemimpin yang memimpin pemulihan. Tentu tugas ini bukan tugas sederhana, tapi sebuah pendekatan yang memerlukan

${ }^{1}$ Agung Gunawan, "Mengelola Konflik dalam Gereja”, Jurnal Teologi Aletheia (Vol.15 No. 4/ Maret 2013): 9-11. kerjasama dari semua pihak. Organisasi gereja yang sudah lama umumnya semua mengalami siklus naik dan turun, dan bila tidak disikapi dan dilakukan perubahan secara benar maka bukan tidak mungkin gereja sebagai organisiasi mengalami kemunduran bahkan kematian. Hal ini sudah terbukti, bahwa kematian gereja secara organisasi bukan hanya dialami di Barat, tetapi juga di Indonesia ini.

Metode yang disajikan dalam orasi ini adalah melakukan suatu studi literatur, observasi dan wawancara, studi induktif Alkitab yaitu kitab Yesaya 42:1-9, dan kemudian hasilnya dinarasikan secara deskriptif tentang menuju pemulihan gereja secara holistik (menyeluruh). Pemilihan teks Yesaya 42:1-9 untuk memberikan otoritas teks dalam kepemimpinan Kristen di mana prinsip pelayanan Yesaya diharapkan menjadi gambaran pemimpin yang membawa pemulihan bagi gereja.

Kajian ini tentunya dibatasi oleh waktu dan tempat penelitian yaitu terbatas pada gereja-gereja yang penulis kunjungi, sehingga kajian lebih lanjut tentang hal ini perlu mendapatkan penelitian lebih lanjut. Hasil yang diharapkan dari tulisan ini adalah adanya pemulihan kepemimpinan gereja dan tulisan ini diharapkan memberikan sumbangan pemikiran untuk memulihkan pemimpin dalam 
pelayanan gereja yang pada akhirnya hal ini akan membawa perubahan kepada kepemimpinan gereja secara menyeluruh.

\section{Latar Belakang Masalah}

Pokok permasalahan yang dihadapi para pemimpin tentang penurunan pelayanan saat ini dapat disimpulkan sebagai adanya masalah dalam panggilan, karakter, kompetensi dan kepercayaan diri. ${ }^{2}$ Ini ditulis oleh Bruce E. Winston yang merupakan dosen kepemimpinan gereja di Regent College Kanada. Temuan ini menjadi unik karena tidak hanya menjadi masalah di Amerika Utara, namun telah menjadi masalah kepemimpinan gereja secara universal di seluruh dunia. Panggilan itu berbicara tentang apakah ada intervensi ilahi dalam memasuki pekerjaan Tuhan. Banyak orang berbicara panggilan sama dengan pekerjaan seseorang.

Tentu panggilan tidak sama dengan pekerjaan seseorang. Artinya, tidak ada pekerjaan yang satu adalah panggilan dan pekerjaan yang lain adalah profesi. Misalnya, menjadi Pegawai Negeri Sipil (PNS) tidak berarti lalu disebut bukan panggilan. Bagi saya itu juga panggilan sepanjang ada intervensi ilahi dalam prosesnya. Intervensi ilahi itu digam-barkan oleh Albert Mohler, Rektor dari Southern Baptist Theological Seminary USA mengatakan panggilan sebagai adanya beban dan kerinduan yang mendalam

\footnotetext{
${ }^{2}$ Bruce E. Winston, The $4 \mathrm{Cs}$ of Christian Leadership", tersedia di https://www.regent.edu/acad/global/publicatio ns/innerresources/vol2iss2/winston.pdf diakes tanggal 1 Juni 2018.

${ }^{3}$ Albert Mohler, "Consider Your Calling: The Call to Ministry", tersedia di
}

akan jiwa-jiwa yang dilayani di mana itu datangnya dari Tuhan yang digerakkan dari dalam oleh Roh Kudus. Yang menentukan adalah motivasi hati yang dituntun Roh Kudus, dan kemudian mendapat Pengesahan dari jemaat atau orangorang yang rohani dan kondisi yang memungkinkan. ${ }^{3}$ Panggilan inilah ditengarai sudah mulai pudar dan diganti dengan banyak persepsi bahwa menjadi hamba Tuhan berarti suatu profesi atau pekerjaan, di mana mentalnya adalah mendapatkan upah, hak, dan kesenangan. Sedangkan tugas pelaksanaan pelayanan disesuaikan dengan upah yang diterima. Tidak sedikit lalu pelayan meninggalkan arena pertandingan ketika mendapatkan berbagai kesulitan dan tantangan.

Hal lain yang disorot dalam kepemimpinan saat ini adalah masalah karakter yang berhubungan dengan sifat-sifat seseorang, yaitu reputasi yang tidak dijaga sebagai seorang hamba Tuhan. Begitu pula ada masalah kompetensi di mana banyak hamba Tuhan sudah tidak lagi me-nguasai keterampilan dasar sebagai hamba Tuhan dalam melayani. Apalagi juga dibarengi dengan adanya masalah kepercayaan diri yang rendah sehingga menghasilkan kepemimpinan yang minder dalam menghadapi para pemimpin di luar tembok gereja.

Di samping itu ada juga yang melihat masalah kepemimpinan dari sudut pandang tidak adanya keberanian dan komitmen. ${ }^{4}$ Tanpa ada kebe-

http://www.albertmohler.com/2004/07/15/con sider-your-calling-the-call-to-the-ministry/ diakses tanggal 11 Juni 2018.

ment", tersedia di

${ }^{44}$ The 4Cs of Leadership Develop-

http://www.columbiasc.edu/about/about- 
ranian maka dipastikan kepemimpinan akan berjalan di tempat dan tanpa komitmen maka pemimpin tidak akan teguh bertahan dalam berbagai tantangan yang akan dihadapi. Janji untuk tetap setia dalam tugas pelayanan tidak lagi dianggap sebagai komitmen yang harus dipegang teguh.

Di bagian lain observasi Derwin L. Gray, masalah yang lain adalah "chemistry" yaitu kemampuan berelasi dengan orang lain (interpersonal skills) dan kolaborasi yaitu kemampuan bekerjasama dengan orang lain. ${ }^{5}$ Kemampuan berelasi memang menjadi banyak masalah dalam kepemimpinan dan kerjasama adalah hal esensial dalam kepemimpinan yang menjadi titik lemah yang perlu mendapatkan perhatian.

Brian Gray menambahkan bahwa masalah kepemimpinan adalah soal keyakinan kita tentang apa yang diajarkan dan dihidupi. Diharapkan semua pemimpin Kristen mendasarkan pengajaran yang berakar dari Alkitab (2 Tim 3:16). Dia harus memiliki penguasaan yang dalam akan Alkitab dan punya komitmen untuk mengembangkan diri dari apa yang Alkitab katakan. ${ }^{6}$ Hal ini menjadi ironi karena justru karena dalam penelitiannya bahwa para hamba Tuhan di Amerika Serikat sangat kurang dalam membaca Alkitab dan berdoa. Bahkan tingkat konsumsi pornografi di kalangan hamba Tuhan meningkat dengan tajam. ${ }^{7}$ Ini menjadi awasan,

columbia-college/the-4cs-of-leadershipdevelopment, diakses tanggal 11 Juni 2018. ${ }^{5}$ Derwin L. Gray, "The 4 C's of Leadership" tersedia di http://www.churchleaders.com/pastors/pastorblogs/157770-derwin_gray_the_4cs_of_leadership.html diakes taggal 11 Juni 2018. karena dalam observasi penulis dalam dunia yang global ini bahwa permasalahan yang sama sedang terjadi di sini. Ini terlihat dari kurang kuatnya fondasi pengajaran Alkitab di antara hamba-hamba Tuhan sehingga ini dapat berdampak dalam aplikasi pelayanan dan etika kehidupan sang hamba Tuhan itu sendiri.

\section{Eksposisi Yesaya 42:1-9}

Masalah di atas perlu disikapi dengan beberapa hal yaitu mencari apa kata Alkitab tentang pokok masalah ini dan apa implikasinya bagi pemulihan kepemimpinan. Penulis memulainya dengan kajian Biblika dari Kitab Yesaya 42:1-9. Kajian Bi-blika dalam tulisan ini bersifat eksposisi tematis di mana bagian-bagian Alkitab tentang pemulihan umat Tuhan dibahas dengan pem-bahasan utama dari Kitab Yesaya 42:1-9 dan melihat pola penggenapan dalam Kitab Injil sehingga bisa menjadi model pemimpin dalam membawa kepada pemulihan.

Teks dalam Yesaya 42 ini diawali dengan Tuhan menyatakan pahitnya pembuangan, lalu datangnya sang Hamba yang membawa keadilan yang bukan hanya bagi bangsa Israel tapi kepada segala bangsa. Pemimpin yang datang adalah sebagai hamba, baik secara pribadi maupun secara komunitas di mana Israel adalah hamba. Motif hamba dalam Yesaya 42 ditegaskan oleh Tyler Mayfield: "One fundamental and fruitful tension in the

\footnotetext{
${ }^{6}$ Brian Gray, "The 4C's of

Leadership", tersedia di

http://bryangrayministries.com/4-cs-ofleadership/, diakses tanggal 11 Juni 2018.

${ }^{7}$ Wawancara dengan Dr. Andrew Brake (dosen Teologi Historis di STT Jaffray), 23 Juni 2018.
} 
biblical text centers on whether the figure represents an individual or a community, the servant as a historical person or all of Israel. Personal or communal." Identifikasi pemimpin hamba dan panggilannya adalah kata kunci melihat pemulihan bangsa Israel.

Narasi sejarah umat Tuhan dimulai dari keluarnya bangsa itu dari perbudakan Mesir, membuat perjanjian lalu menuntun ke Kanaan sebagai tanah perjanjian yang walaupun melewati padang gurun. Lalu mereka menjadi sebuah bangsa dan membangun Bait Allah. Selama berabadabad dalam sejarah kerajaan Israel mereka menang dan kalah. Mereka seringkali menyimpang dan meninggalkan Tuhan, tapi para nabi memanggil mereka kembali. Lalu enam abad sebelum masehi di mana Babel mengalahkan Israel. Bangsa Israel ditawan dan dibuang ke tanah Babel dalam kurun waktu 70 tahunan, dan pembaca Alkitab akan merasakan pahitnya pembuangan dan bagaimana Israel menangis karenanya. Mazmur berkata: "Di tepi sungai-sungai Babel, di sanalah kita duduk sambil menangis, apabila kita mengingat" (137:1). Kemenangan Babel atas Israel dalam narasi kitab Yesaya sangat absolut, di mana Israel hancur secara politik, sosial, ekonomi, agama dan peristiwa ini masih diingat dalam sejarah Israel modern saat ini.

Pertanyaan mendasar dalam konteks pemulihan umat Allah dan kepemimpinan di mana bangsa Israel terpuruk adalah apakah Tuhan masih

\footnotetext{
${ }^{8}$ Tyler Mayfield, “God's spirit, God's servant, God's delight" tersedia di https://www.workingpreacher.org/preaching.a spx?commentary_id=3132 diakses tanggal 22 Juni 2018.
}

sebagai Tuhan? Apakah masih ada harapan untuk pemulihan kepemimpinan umat Allah? Di kitab ini dipaparkan bahwa Tuhan ditegakkan siapa Dia dan bagaimana karya-Nya dengan mengutus hambaNya sebagai pemimpin yang membawa pemulihan. Di sini Yesaya memproklamirkan pemimpin yang akan memulihkan umatNya. Ekposisi sederhana dari Yesaya 42:1-9 memberikan beberapa makna tentang pemulihan bangsa lewat pemimpin: ${ }^{9}$

Pertama, Tuhan akan mengirim hamba yang dipenuhi Roh Kudus dan bukan pemimpin tirani (ayat 1-3). Ungkapan "buluh yang patah tidak akan dipadamkannya" dan "sumbu yang pudar tidak akan dipadamkannya" menggambarkan kedatangan pemimpin yang menjadi pembebas, penguat dan pada saat yang sama menjaga kebenaran dan hukumhukum Tuhan. Ia penegak kebenaran dan sekaligus menyatakan kasih dan setia Tuhan. Kata kunci adalah hamba Tuhan yang dipenuhi Roh Kudus.

Kedua, Tuhan menegakkan keadilanNya di bumi sebagai gambaran Dia dalah Tuhan untuk semua bangsa dan Tuhan akan menyertai hambaNya sampai keadilan Tuhan ditegakkan ke segala pulau (ayat 4). Pusat pemberitaan adalah pada keadilan Allah yang dibawa oleh para pemimpin-pemimpin yang ditunjuk Tuhan.

Ketiga, rencana Tuhan adalah umat Tuhan dipanggil untuk menjadi alat berkat. Mereka dilepaskan dari pembuangan untuk menjadi berkat.

\footnotetext{
${ }^{9}$ Disarikan dari ekposisi oleh Amy Oden, "Commentary on Isaiah 42:1-9" tersedia di

https://www.workingpreacher.org/preaching.a spx?commentary_id=1938 diakses tanggal 12 Juni 2018.
} 
Pemimpin dan umatNya dipanggil untuk "membuka mata yang buta, untuk mengeluarkan orang hukuman dari tempat tahanan dan mengeluarkan orang-orang yang duduk dalam gelap dari rumah penjara" (ayat 5-7).

Model pemimpin yang digambarkan dalam kitab Yesaya kemudian digenapi pada diri Yesus sebagaimana ada di dalam kitab-kitab Injil. Bahwa Yesus datang ke dalam dunia sebagai terang dan kegelapan tidak akan mengalahkannya (Yoh 1:5) yang adalah kegenapan Yesaya 42:6 "menjadi terang bagi bangsa-bangsa". Baptisan Yesus dalam Matius 3:13-17 adalah kegenapan Yesaya 42:1 yaitu Roh Allah ada padaNya dan suara dari surga memproklamirkan "Inilah anak yang Kukasihi kepadanyalah Aku berkenan"

Lalu dalam kitab Lukas, Yesus dinyatakan sebagai hamba yang menegakkan keadilan, di mana dikatakan: "Roh Tuhan ada pada-Ku, oleh sebab Ia telah mengurapi Aku, untuk menyampaikan kabar baik kepada orang-orang miskin; dan Ia telah mengutus Aku untuk memberitakan pembebasan kepada orang-orang tawanan, dan penglihatan bagi orangorang buta, untuk membebaskan orang -orang yang tertindas, untuk memberitakan tahun rahmat Tuhan telah datang (Lukas 4:18-19). Yesus model pemimpin sejati yang melakukan pemulihan. Penggenapan Yesus dalam kitab Yesaya bukan hanya pada kelahiran dan kematian serta kebangkitan-Nya saja, tetapi telah menggenapi kepemimpinan yang membawa kepada pemulihan. Kepemimpinan yang membawa pemulihan ini merupakan 'blue-print' bagi model kepemimpinan Kristen masa kini.

\section{Menuju Pemulihan Kepemimpinan Gereja}

Lewat eksposisi tematis kitab Yesaya ditemukan model kepemimpinan yang dapat memulihkan umatNya yang tergenapi dalam kehidupan Yesus. Maka dalam implikasinya bagi pemulihan kepemimpinan gereja, ada beberapa pesan yang perlu disampaikan kepada para penamat sehingga mereka dapat menjadi agen perubahan di gereja dan masyarakat:

Pertama, perlu kembali kepada panggilan yang jelas. Menjadi agen pemulihan memerlukan panggilan yang pasti dari Tuhan. Panggilan itu datangnya dari Tuhan dan tidak pernah didapat lewat pendidikan yang diterima. Panggilan tidak boleh hanya difahami sebatas dalam tembok gereja, tetapi panggilan kepada se-luruh bangsa dan dunia ini adalah ladang. Ungkapan yang terkenal dari John Wesley adalah "the world is my parish" yaitu dunia ini adalah gereja-ku. Ini berarti apapun nanti pelayanan yang diambil entah menjadi hamba Tuhan penuh waktu di gereja, gem-bala, pendeta, penginjil, guru, dosen, karyawan, pengusaha, tentara, polisi, politikus, pedagang, bisnis profesional semuanya harus berakar dari sebuah panggilan Tuhan. Tanpa itu apapun pelayanan para pemimpin akan menjadi sebuah profesi biasa. Bila memulai sesuatu pelayanan mulai namun tidak dengan panggilan pela-yanan yang sungguh, maka pelayanan itu akan kehilangan rohnya dan tidak ada kegairahan (passion) di dalamnya.

Jelas panggilan memang bersifat sangat subyektif tapi paling penting dalam kepemimpinan. Ia laksana seorang yang sedang jatuh cinta, di mana susah mendefinisikan- 
nya tapi dapat dirasakan. Ia adalah gabungan antara tujuan yang Tuhan taruh di hati dan kerinduan yang dalam di hati seseorang. ${ }^{10}$ Panggilan dapat digambarkan seperti kitab Yesaya 6:18 di mana adanya bara api dari mezbah Tuhan yang ditaruh dalam bibir dan hidup sang pemimpin. Pemimpin yang dijamah Tuhan inilah yang akan mengubah dunia di mana kepemimpinan yang dimulai dari panggilan menghasilkan pemimpin visioner, diurapi dan punya agenda dan tujuan yang jelas. Ini sangat ber-beda dengan para pemimpin yang hanya mengisi slot kepemimpinan dalam pelayanan. $^{11}$

Kedua, pentingnya karakter yang bertumbuh. Hal esensial dalam kepemimpinan adalah soal karakter seseorang. Ada banyak masalah kepemimpinan yang sulit diselesaikan adalah berhubungan dengan karakter seseorang. Biasanya susah dilacak karakter seseorang bila dia masih menjadi bawahan atau orang biasa. Tapi jika sudah ditempatkan pada posisi pemimpin, baru tampak karakter kepemimpinannya.

Karakter pemimpin itu dapat dibentuk terutama oleh Roh Kudus dan lewat proses mentoring dan me-miliki hati hamba. Karenanya diharap-kan para penamat dalam memulai pelayanan dan tugas bersedia diasuh di bawah bimbingan seorang senior sehingga terbentuk karakter kepemimpinannya. Ada beberapa karakter yang harus dimiliki pemimpin: Yang pertama adalah bagaimana pemimpin memimpin dengan contoh atau ke-

${ }^{10}$ Dave Kraft, Leaders Who Last. Wheaton (Illinois: Crossway, 2010), 78.

${ }^{11}$ Ibid, 79.

${ }^{12}$ Disarikan dari Daniel Ronda, Leadership Wisdom: Antologi Hikmat Ke- teladanan; kedua, memimpin dengan integritas; dan ketiga, memimpin dengan memiliki jiwa dan roh atau ada spirit akan panggilan pelayanan (sense of calling). ${ }^{12}$

Dari prinsip di atas maka dapat lagi dijabarkan pemimpin yang berkarakter adalah memiliki hal-hal sebagai berikut: 1) integritas; 2) adil; 3) jujur; 4) suka menolong; 5) suka berbuat baik; 6) tidak diskriminatif; 7) rajin; 8) menjaga kehormatan diri; 9) tidak suka berselisih; 10) mudah bergaul dan tidak jaga jarak; 11) mampu kontrol diri; 12) menghindari kemunafikan; 13) bermoral; 14) tidak boros; 15) menghargai pemimpin; 16) mendengarkan; 17) kontrol dalam berbicara; 18) tidak ada niat jahat. Ini simpulan dari beberapa observasi yang penulis dapatkan tentang karakter yang diperlukan sebagai pemimpin. ${ }^{13}$

Ketiga, kompetensi yang mumpuni. Keahlian seorang pemimpin tidak serta merta terbentuk dalam pendidikan. Kompetensi itu adalah proses panjang dan bahkan seumur hidup. Itu sebabnya ada pepatah "longlife learning" yang dimaknai bahwa belajar itu adalah proses seumur hidup. Disadari bahwa kesalahan dalam kepemimpinan adalah ketika seseorang berhenti belajar, berhenti membaca, berhenti bertanya. Ini sebenarnya hal yang secara ilmiah dapat dipertanggung-jawabkan untuk membentuk keahlian seseorang. Namun bila ini hilang dalam kepemimpinan, maka dipasti-kan kepemimpinan akan berjalan di tempat. Di dalam pengandaian, jika seorang

pemimpinan cet. Kedua (Bandung: Kalam Hidup, 2015), 35-40.

${ }^{13}$ Ibid. 
dokter atau pilot diwajibkan mengikuti seminar dan pelatihan dalam satu tahun untuk dapat diper-panjang lisensinya, maka layaknya pemimpin gereja memiliki tekad yang sama bahwa tanpa keterampilan tam-bahan rasanya tidak layak melanjutkan tugas sebagai seorang pemimpin.

Keempat, kepercayaan diri yang elegan. Masalah terbesar dalam kepemimpinan adalah kurangnya kepercayaan diri (confidence) akan diri dan kemampuannya. Ini terjadi dalam masa pembentukan seseorang ketika dia dibesarkan. Banyak talenta dan keahlian terpendam karena tidak merasa yakin akan dirinya sebagai makhluk berharga ciptaan Tuhan. Rasa percaya diri yang rendah akan membuat kepemimpinan menjadi bermasalah mengingat kompleksnya pergumulan seorang pemimpin. Apalagi pemimpin adalah seseorang yang berdiri di depan, di atas panggung dan sekaligus seluruh kehidupannya menjadi sebuah sorotan bak ikan di sebuah toples aquarium di mana seluruh mata me-lihat sepak terjangnya. Bila tanpa suatu keyakinan diri bahwa pemimpin itu berharga dan ciptaan Allah yang mulia maka dapat dipastikan sang pemimpin akan mudah patah ketika berhadapan dengan kritik, mudah stres ketika berjumpa dengan tantangan dan menjadi rapuh ketika bersua dengan ancaman. Banyak pemimpin lalu ber-sembunyi dan membuat topeng-topeng psikologis baru yang kemudian menambah runyam kepemimpinan itu sendiri. Kepercayaan diri itu sendiri hendaknya dipahami sebagai kemam-puan menerima diri apa adanya baik kelebihan maupun kekurangannya dan berdamai dengannya. Lalu kemudian maju melangkah dengan kepastian dan keyakinan diri atas kelebihan dan kekurangan yang ada pada diri seseorang.

Memiliki kepercayaan diri sangat penting sehingga pemimpin mampu dan tangguh pada waktu membayar harga kepemimpinan. Tanpa kepercayaan diri yang kuat maka pemimpin tidak akan sanggup menghadapi tekanan dan penderitaan yang harus dilalui. Dengan kepercayaan diri yang kuat maka pemimpin akan disiapkan untuk mampu meng-ambil risiko, menunjukkan kesabaran dan ketekunan dalam kondisi yang berat, bertahan dalam berbagai kritik yang bertubi-tubi datang, sanggup memikul kesepian yang tiada tara, mampu bekerja dengan sumber-sumber daya dan dana yang terbatas, dan tetap bertahan walaupun mengalami kelelahan secara fisik dan emosional. ${ }^{14}$

Kelima, kolaborasi yang meluas. Dunia saat ini berjejaring dan tanpa kerjasama maka dipastikan seseorang mengalami keterasingan di tengah keramaian jejaring. Eddie Gibbs berkata, "Kepemimpinan berbicara tentang menghubungkan, bukan mengendalikan. Kepemimpinan ialah mengenai mempersatukan sejumlah orang demi tujuan sinergi kreatif. Oleh karena era informasi bergerak cepat sedangkan pengetahuan serta pengalaman sangat beragam, para pemimpin dari gereja-gereja baru mengenali kebutuhan mereka untuk mengoperasikannya dalam konteks tim. Pelayanan berbasis tim memampukan mereka untuk saling menarik keluar kekuatan masing-masing, dan

${ }^{14}$ Disarikan dari Eddie Gibbs, Kepemimpinan Gereja Masa Mendatang (Jakarta: BPK GM, 2011), 201-220 
berkontribusi dari anugerah yang mereka terima dari Allah, termasuk dari pengalaman hidup mereka, demi kebaikan bersama." 15

Di sini pemimpin harus menyadari bahwa setiap orang dan atau lembaga punya potensi besar sehingga diperlukan sinergi untuk mencapai hasil yang maksimal. Pengerdilan suatu organisasi terjadi bila kepemimpinan mulai tertutup dan hanya menjadikan diri sebagai obyek dan bukan subyek dari kerjasama. Artinya, seringkali para pemimpin hanya memperhatikan keuntungan jangka pendek untuk diri dalam menjalin sebuah kolaborasi. Kolaborasi dimaknai sebagai sebuah kerjasama berdasarkan tugas dan kelebihan masingmasing yang membentuk sinergi sehingga menghasilkan suatu yang lebih besar dari sebelumnya. Kolaborasi penting mengingat bahwa pekerjaan Tuhan memerlukan kecepatan yang lebih baik mengingat pertumbuhan manusia yang juga sangat cepat di muka bumi ini. Menghadirkan kolaborasi berarti menghadirkan konsep mempercepat kerajaan Allah di muka bumi ini lewat kerjasama sebagai saudara di dalam Tuhan.

\section{Kesimpulan}

Pemulihan kepemimpinan bukanlah proses yang berlangsung satu kali tapi proses terus menerus dan bekepanjangan. Ia dimulai dari pemulihan pribadi dan pemulihan organisasi. Sebuah proses yang bisa saling mendahului atau hadir bersamaan. Namun prinsip dasarnya adalah dimulai dari karya Roh Kudus yang memanggil para pemimpin untuk membawa pemulihan gerejaNya secara me- nyeluruh. Pemulihan kepemimpin-an memiliki kunci yaitu pemimpin itu sendiri. Maka sang pemimpin merupakan penggerak utama untuk mendapatkan pemulihan. Figur sang pemimpin yang dipulihkan rujukannya ada pada kehidupan dan karya Yesus, yang juga merupakan penggenapan model kepemimpinan yang dinubuatkan dalam Kitab Yesaya. Kepemimpinan yang dipulihkan paling tidak telah mememuhi kriteria yaitu: pertama, dimulai dengan memiliki panggilan yang jelas; kedua, karakter yang dewasa dan mumpuni yang menunjuk-kan sebuah intergritas yang menekan-kan kebenaran dan kasih karunia diterapkan secara simultan; ketiga, kompetensi yang semakin terasah dalam proses perjalanan sang pemimpin sehingga tidak dikenal istilah pemimpin yang stagnan alias tidak berkembang tapi sebaliknya keahliannya semakin bertumbuh dalam perjalanan waktu; keempat adalah kepercayaan diri yang kuat serta mampu menghadirkan sebuah keyakinan bersama untuk menggapai visi dan misi; serta kelima, mampu dan siap melakukan kolaborasi dengan berbagai pihak yang membawa kepada perluasan pelayanan baik skala lokal, regional, nasional bahkan internasional.

\section{DAFTAR PUSTAKA}

"The 4Cs of Leadership Development",http://www.columbiasc. edu/about/about-columbiacollege/the-4cs-of-leadershipdevelopment, diakses tanggal 11 Juni 2018.

\footnotetext{
${ }^{15}$ Ibid, 114.
} 
Gibbs Eddie, Kepemimpinan Gereja Masa Mendatang (Jakarta: BPK GM, 2011), 201-220.

Gray Brian, "The 4C's of Leadership", tersedia di http://bryangrayministries.com 14-cs-of-leadership/, diakses tanggal 11 Juni 2018.

Gray L. Derwin, "The 4 C's of Leadership" tersedia di http://www.churchleaders.com/ pastors/pastor-blogs/157770derwin gray the 4cs_of_leadership.html diakes taggal 11 Juni 2018.

Gunawan Agung, Mengelola Konflik dalam Gereja, Jurnal Teologi Aletheia (Vol.15 No. 4/ Maret 2013) Mayfield Tyler, "God's spirit, God's servant, God's delight" tersedia di https://www.workingpreacher. org/preaching.aspx? commentar y_id=3132 diakses tanggal 22 Juni 2018.

Mohler Albert, "Consider Your Calling: The Call to Ministry", tersedia di http://www.albertmohler.com/ 2004/07/15/consider-yourcalling-the-call-to-theministry/ diakses tanggal 11 Juni 2018.

Oden Amy, "Commentary on Isaiah 42:1-9" tersedia di https://www.workingpreacher. org/preaching.aspx?commentar $\mathrm{y} \_\mathrm{id}=1938$ diakses tanggal 12 Juni 2018.
Ronda Daniel, Leadership

Wisdom: Antologi Hikmat

Kepemimpinan cet. Kedua (Bandung: Kalam Hidup, 2015), 35-40.

Wawancara dengan Dr. Andrew Brake (dosen Teologi Historis di STT Jaffray), 23 Juni 2018.

Winston E. Bruce, The 4Cs of Christian Leadership", tersedia di

https://www.regent.edu/acad/gl obal/publications/innerresource s/vol2iss2/winston.pdf diakes tanggal 1 Juni 2018. 


\section{BIODATA PENULIS}

Daniel Ronda lahir di Denpasar, 12 April 1966. Penulis menyelesaikan studi S1 di STT Jaffray Makassar; menyelesaikan program studi M. Div di bidang "Pastoral Studies" di Alliance Biblical Seminary; menye-lesaikan program studi Th. M di bidang Teologi Sistematika di Asia Graduate School of Theology, Manila Philippines; telah mengikuti Program Studi "Doctor of Ministry" bidang Preaching di Absury Theological Seminary, USA; dan D. Th bidang Teologi dengan ujian negara di STT Jaffray Indonesia. Saat ini penulis menjabat sebagai dosen STT Jaffray dan Ketua Umum Gereja Kemah Injil Indonesia. Penulis juga aktif sebagai Asesor Badan Akreditasi Nasional Perguruan tinggi (BAN-PT) dan juga sebagai Asesor Beban Kerja Dosen (BKD) PTT/AK Dirjen Bimas Kristen Kemenag RI. Penulis juga aktif sebagai penulis buku dan jurnal. 